\title{
Desolation and Displacement in Ayi Kwei Armah's Why Are We So Blest?
}

\section{S Geetha Nirmal}

Assistant Professor of English, Nesamony Memorial Christian College, Marthandam, India

\begin{abstract}
Armah is an austere writer who criticizes the evils in the society. Most of the works are related to the sufferings of the Ghanaians after their independence. As seen in all the nations which were the colonies of the Britishers, Ghana too experienced the trauma which made the country too loose its identity and also made the natives to alter their style of living. This as the background Armah created his characters who felt alienated, desolated and also displaced in other nation and also in their own native land. Through the characters of Modin and Solo Armah gives out the sufferings and also the struggle to overcome the sufferings in the society which lost its values and made the characters to be totally inappropriate in the situation. This paper tries to elucidate the pain and pathos of the characters who were suffering because of desolation and displacement.
\end{abstract}

Keywords_Desolation, Displacement, Alienation, Trauma, Colonialism.

Armah is a prominent writer who exposes the evils in the society. Because of the social, political and economic decay of the society the natives of Ghana suffered a lot to survive and struggled hard to overcome the suppression. Most of the people were psychologically occupied with the Western thoughts which made them to feel inferior to the Westerners and also to the fellow beings. They felt a kind of displacement in the society. In order to change this condition in the society Armah has created the characters who struggles hard and also protest against the system which prevails in the society which is considered to be the one which has lost its traditional and moral values.

In Why Are We So Blest? Ayi Kwei Armah depicts an African waste land where the total society has faced the decay and the native citizens trying to establish themselves in the society they belong. According to Robert Fraser, "In contrast with Armah's previous novels, Why Are We So Blest? moves from the tight circle of largely Ghanaian concern to embrace a world view, a total vision of the contemporary world whose limits of reference are defined as America, the Muslim Maghreb and SubSaharan Africa"(2).Armah has used his characters to establish their own culture and identity in the contemporary world. But because of the colonialism and also the influence of the western ideologies even the people in power were behind the materialistic world. In Derek Wright's words, “the community's would be revolutionary saviors are revealed as paralysed and emasculated by the luxuries of westernized exile"(3).

Armah has portrayed the characters who has been dislocated and lost their identity because of the Western influences. Modin, a lonely African studying in the United States which is totally different place for him with western culture, falls in love with Aimee, a white American girl who is sexually aggressive. Her uncle was, she discovers, a soldier who had taken part in massacres in colonial Africa. She conceives of sex in racist and sadistic terms. She approaches sexual satisfaction by concentrating on a fantasy in which she is the wife of a colonial officer seducing her servant-boy Mwangi while expecting her husband's return from the bush at any moment. This fantasy too is targeting at the diversity in the culture and also the thought of superiority over the black people.

Modin, despite his knowledge of Aimee's origin and her fantasies, cannot overcome his love for her. Because of this Modin convinces her and they both travelled to Africa to take part in the liberation struggle in Congheria. Aimee exhibits an immense desire to be a 'revolutionary' both in the public and also the private affairs. Even though she has the desire to be a revolutionist her inner thought will be always different from the concepts of the Africans. While Modin returned to Africa even in his own nation he became an odd person. At the end of the novel Aimee acts out a version of her fantasy in grim reality. A group of French men tie Modin to their car, then rape Aimee one by one, and cut off the end of 
Modin's penis. After this incident Modin feels lonely in his own nation.

Armah delegates much of his narrative to indicate the contrast in the culture of the characters. The characters who feel lonely and also isolated from the society is depicted in the novel. One of the most outstanding features of the novel is that Armah attempts to elevate this case history to the level of a universal metaphor of relations between white and black where both discrimination is seen. In Why Are We So Blest? the social and psychological factors which demarcate the distinction between the white and the black, the oppressor and the oppressed are portrayed in terms the contrast of the characters. Modin's fatal attraction for his white mistress Aimee is presented in terms of Africa's contact with Europe which had left a debilitating impact on the native mind. The entire story of Why Are We So Blest?comes to us through Solo Nkonnam either in his own words or through passages from the diaries of Modin and Aimee edited by him. Modin and Aimee are considered to be the tortured figures as they both suffered the cultural contrast and the consequences of the same. They hardly speak to each other face to face, since Aimee's watchful jealousy comes like a wall between them.

Solo and Modin most vitally focus on the major thematic interest, namely, the twin problems of national reconstruction and the establishment of their self in the society which belongs to Modin. The significantly named Solo is "a ghost, wandering about the face of the earth, without a contact with the life about him" (11). He is a translator in the people's union of Congheria, seat of the government in exile. He carries with him the twin failure of his own past and the burden of African past. As the Africans lost their values their realization of that toot made them to oppose the aspects imposed on them. Because of this Solo tried to bring out some sort of revolution in the society. His participation in the revolutionary struggle leaves him with strong memories of failure and inadequacy on the one hand and desolation on the other. "Once full of love for his people and the revolution" (48), he has come to see his society as full of people "already empty of their souls, incapable of flight and not yet buried" (113) and the revolution as so many "cracked promises and maimed bodies of lost believers" (13). Armahpicturises the traumatic effect of the colonization on the minds of the African people.

Although the details of Solo's participation in the struggle and the reasons for his failure are not specified, we come to realize through the bits and pieces of his reminiscences that he opted out of the revolution because of his reluctance "to pretend." or to lead the same life which he feels himself as an alien. From his realization it can be safely deduced that something went wrong not with Solo's participation but with the nature and orientation of the struggle itself. He needs to escape from the isolation he feels. Solo sadly recalls:

To live well now means to develop as highly as possible the ability to do one thing while saying, and preferably also thinking, another thing entirely. The successful lives are those with entrails hard enough to bear the contradiction and to thrive on it. Then there are those who for some explicable reason want to bring what they do and what is donearound them into the same territory as what they think and what they dream. These are the losers, life's failures. (14)

Like the Man in The Beautyful Ones Are Not Yet Born, Solo refuses to compromise on basic values he cherishes most and is consequently faced with the prospect of being labelled as a loser. Since he cannot deceive himself as others do he is left with no goal but "to fill time, to survive emptiness" (232). Armah indicates the selfisolation of Solo from the decayed society. He finds himself incapable of the creativity of writing and sticks with his safer translations. He says: "To write would have required the knowledge that what I write is of some value and is not merely the dishonest exercise of a mind which for some reason does not occupy itself with necessary things. I do not have this conviction" (12). Solo spends his time in trivial pursuits, occasional bursts of translating, and in hanging around the offices of the people's union of Congheria where he seems to have the status of an affectionately regarded invalid, to be tolerated but not trusted.

In Why Are We So Blest? once again Armah traces the impact of alienation and isolation on the mind of the individuals who have their education outside their native country. Modin is an isolated individual in America who cannot identify himself with the alien culture. As in some societies he was not able to communicate with the natives. People will consider him as a person who is educated and having the modern thought and had lost all the traditional values. The great struggle Modin faced is the kind of isolation he felt in his own nation. He feels the utter alienation of himself from his people and his past:

I feared the urging to isolate myself to cut myself off from where I came from, forget my origins and make the thinly glided present all my history. The urging was seductive because my own pain and the social pain of being an African at a time like this repelled the young mind fleeing in search 
of a calmer life. The ease of the present reinforced the repulsion of the past, making the present, offered identity far easier to accept. (162)

Modin tries to overcome this isolation in America by being with the peoples surrounded him. But he was not able to because he was surrounded by the white people. The white scholars attempt to make him feel "all special on account of being with them" (121). They call him 'unique' and 'unusually intelligent' which made him to feel the sense of self elevated which made him to be different from others in the society. Armah indicates all the aspects in life where a man will feel being alienated. Even the simple things in life where men is different from other fellow beings will make them to be special creatures which makes others to isolate the particular one. From the moment of his arrival in the States, Modin's clear-sighted intelligence perceives the implications of his training with great insight. From the beginning he is made to feel that the clue to his acceptance lies not in the fact that he is able but that he is an intelligent African, something hardly to be thought of.

Despite Modin's continuing protests, the Committee persists in regarding him as an alien and some kind of performing animal. It is in vain that he counters this argument by mentioning that his friends back home are every bit as gifted as he. But none cared him and all considered him as an extraordinary person so that he found himself alienated from his fellow beings. In his academic side the early isolation made him to think him as a person who has been in double alienation. He is unable to translate his ideology into action nor he can remain attached to where he is best known by his colour and race and not through his individuality. He rejects a scholarship offered on these humiliating grounds, for to accept the money would be to accept the assumption underlying it. When Oppenhardt says, "With your intelligence, you'll grow in the best company" (161),

Somewhere between Solo and Modin we get the most vivid novel form account ever given of what it is that European education does to the African. Modin's diary installments are simply and consistently uncompromising on the he is made as a person who has no identity in the world where he exists. He says, "The search for knowledge should not be synonymous with increasing alienation and loneliness. In our particular circumstances it is so. It has been planned that way" (32).

Modin begins to realize that his life is totally a creation of the whites and that his independent identity is an illusion. He is dominated economically, socially, and culturally. He is now convinced that he is a person who is isolated from both sides and for the whites even if he is educated he is not considered as one among the elites because of the colour of his skin. When he returns to his native there too because of his education he is isolated by the fellow beings.. As an educated modern Black spirited away by an arbitrary scholarship from his own culture, he is being trained to plunder his own people on behalf of his masters, as did his factor predecessors.

Modin slowly realizes that his soul has become the property of the whites. He has been alienated from his own nation to acquire a place among the whites where he realises that he is isolated by them too. Armah points out that he is isolated from his own nation and because of his education and the influence of the material wealth he has changed himself as an object of the western thoughts. But later he realised it is not the culture which changed him but his own thoughts because of alienation. He asserts:

I am frightened now. These things I thought I was doing freely, out of my own desire -they are also part of the larger scheme that aims at our destruction. My friendships have been different invitations to different kinds of death, calls to a spiritual disintegration far beyond the merely social disintegration. Africa has suffered since how many centuries? This throwing out of the self, to have it caught in a direction not first determined by theself itself, the projection of our persons in alien directions, this alienation with no overt, no visible force, this is the sign that our death complete. Europe has no need to destroy us singly any more. The force of our own death is within us. We have swallowed the wish for our own destruction. (158-59)

It is not only the feeling of isolation experienced by the characters but also the loosing of their self-identity and also the national identity is exposed by the author. Modin is a person with great vision suffers lot to survive in the nation which is occupied with different ideologies. His views were not even accepted by the normal people and he was treated as an alien in his own nation and the other. Thus through the character of Modin the author has indicated the pathetic condition in the society which is not permitting a person to establish his own identity in the land in which he belongs to. Armah exposes the condition and expects the change in the society which is totally corrupted and lost it values because of the westernization and modernization. 
International Journal of English Literature and Social Sciences, 5(5)

Sep-Oct 2020 / Available online: https://ijels.com/

\section{REFERENCES}

[1] Armah,AyiKwei. Why Are We So Blest? London : Heinemann, 1974.

[2] Derek Wright, ed. Critical Perspectives on Ayi Kwei Armah. Washington, D.C.: Three Continents Press, 1992.

[3] Frazer, Robert. The Novels of AyiKweiArmah. London: Heinemann, 1980. 